\title{
Dose Manegement Proguram in Radiation Therapy
}

\author{
国立大阪病院放射線科 小西佳之 土井豊造
}

目的

放射線治療の日常における線量及びデータ一管理 業務を容易にするとともに、近畿管内国立病院療養 所における放射線治療の精度管理向上を目的亡する。 使用機器および方法

Machintosh コンピューター 計算ソフトExcel v5 市販計算ソフトExcel v5 を利用し、楾量管理プロ グラムを作成した。画面構成をメニュー、基本データ

（図 1）、係数、治療カウント（図 2）その他データ

（電子線）資料、管理画面とし、それぞれの内容を 解りやすい項目として画面上に表示した。

電子線の基本デー夕画面を（図 3）に示す。

日常の業務において、X線の場合、係数値等の変更 が無い限り、治療カウント画面（図2）より、深さ、 照射野、標的線線量、フィルタ一等の設定のみで治療 カウントを得ることができ、電子線の場合は各コーン 值のデーター画面より使用コーンの値をペースト（図 4) することにより治療カウントを得ることができる。

また指示値、電離量百分率曲線から、仮の電離半値 哚、電離半価深を得、仮の入射エネルギ一、入射エネ ルギー、pf 値、水の衝突阻止能比を算出し、深部量百 分率から各深さの線量を得た。（図3）各画面の各媣 さにおける測定値、係数値等の代入、変更による計算 はExcel 関数、近似式、マクロ機能を利用することに より自動的に行えるようにした。

基本デー夕、係数画面の各係数、計算項目に值を代 入することにより、治療カウント画面の係数伹、計算 值も自動的に変更、算出する機能とした。各デー夕、 係数值等の使用、計算の方法は基本的に標準測定法に 基ずいて行った。管理画面からは、日常の测定データ 一から環境（K1）とMF值の変動についてグラフ化す ることにより、その変動率を把握することができる。 結果および考察

従来使用していた Basicによるプログラムに比べ、 測定䛧、係数等の変更、代入が、それぞれ項目として 画面上に表示されているため数值の変更に対応しやす く非常に簡便に使用できる。施設、機器の違いによる 必要な変更内容が解りやすく数值の代入が簡単なため 他施設間での共通した使用がより可能となり全体とし ての精度向上に役立つことができる
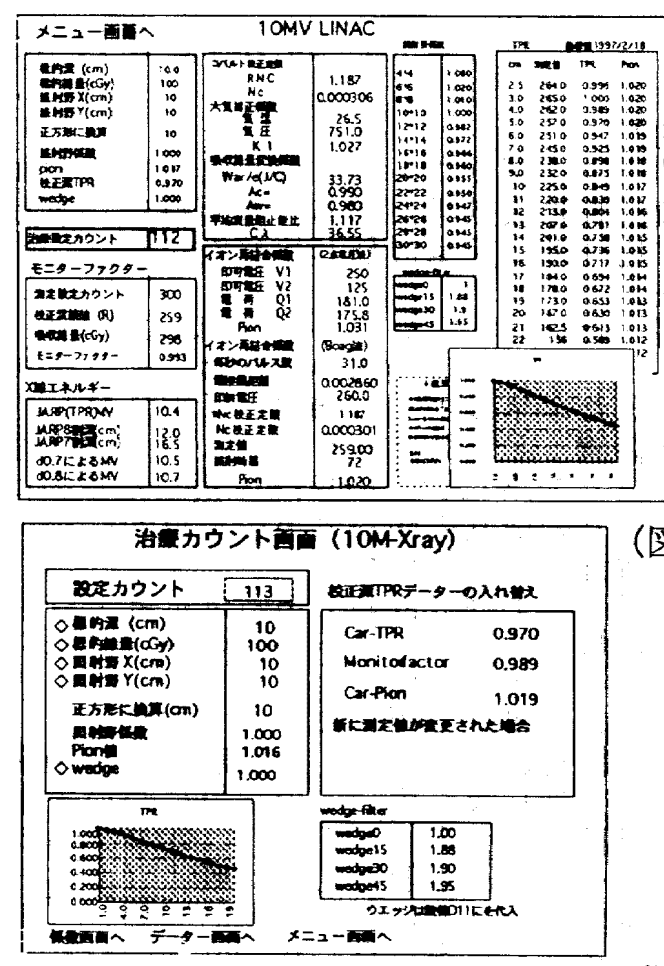

(図 1)

(図 2)
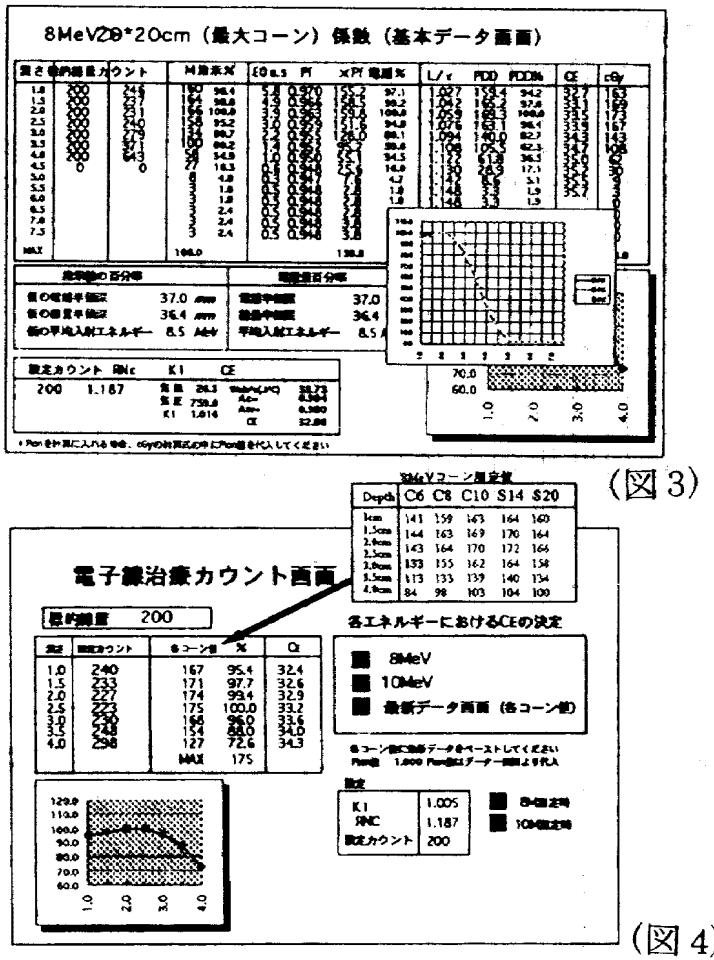

(図 4) 